\title{
Grasslands Kara cocksfoot: a productive cultivar under lax grazing
}

\author{
D.R. STEVENS, G.S. BAXTER, A. STEWART ${ }^{\mathbf{1}}$, M.J. CASEY and K.B. MILLER \\ AgResearch, Private Bag 50022, Gore \\ 'Pyne Gould Guinness Ltd. PO Box 6068, Christchurch
}

\begin{abstract}
Field testing compared the agronomic performance of Grasslands Kara cocksfoot (Dactylis glomerata L.) with other commercially available cocksfoot cultivars and perennial ryegrass (Lolium perenne L.) in Southland and Canterbury. Animal performance was also assessed in southland. Kara cocksfoot had the highest establishment score of the cocksfoot cultivars in Canterbury but was slower to establish than ryegrass. Annual yields of Kara cocksfoot were $7 \%$ lower than Wana in Southland. The yield of Kara in Canterbury was 131 and $74 \%$ greater than ryegrass in a dry summer and autumn respectively. In Southland the pasture production from Kara under goat grazing was never significantly different from that of Nui ryegrass. The liveweight gains of both sheep and goats on Kara pastures were similar to those on ryegrass. Pasture digestibility was lower for Kara than Nui ryegrass pastures in spring but similar in summer and autumn. Pasture protein content was higher for Kara than Nui pastures in spring and similar in summer and autumn. The leaf-stem ratio of Kara was higher than Nui in spring but similar in summer and autumn. Rust tolerance of Kara was high and similar to Wana and Porto. The results from animal performance and pasture parameters show that Kara has a high feeding value. The effects of winter frost damage were greater on Kara and Wana than on Apanui due to their winter activity.
\end{abstract}

Keywords animal performance, Dactylis glomerata L., cocksfoot, establishment, frost damage, pasture production, pasture quality

\section{Introduction}

The use of cocksfoot (Dactylis glomerata L.) in drier environments and withlowerfertility soils has long been part of New Zealand farming (Levy 1951). Cocksfoot have lower digestibility than many other grasses (Minson et al. 1964) and rust infection in autumn makes them unpalatable (Rumball 1982). Rumball (1982) addressed both of these problems during the breeding of Grasslands Kara cocksfoot, an erect cultivar suitable for laxer grazing by stock classes like cattle.
This paper summarises the herbage and animal production information available for Kara cocksfoot in Southland and Canterbury and compares it with alternative cocksfoot cultivars and ryegrass. These data will help farmers and farm consultants make better informed decisions about the use of Kara cocksfoot in the South Island.

\section{Materials and methods}

\section{Experiment one}

Kara, sown with Grasslands Huia white clover (Trifolium repens L.) was tested under sheep grazing at the DSIR Grasslands regional station at Gore, Southland, in the period 1980-1983. Kara was compared with three other cocksfoot cultivars Grasslands Apanui, Grasslands Wana and Saborto under infrequent grazing (6 week regrowth) to a residual height of $10 \mathrm{~mm}$ in four replicates of $10 \times 15 \mathrm{~m}^{2}$ individually fenced plots. Pasture yield and botanical composition were measured at each grazing date and data analysed by season and year.

\section{Experiment two}

Kara was included in an evaluation of nine pasture mixtures grazed by goats for three years (1988-1991) and then sheep for one year (1991-1992) at the DSIR Gore Research Centre. Southland. Results from the comparison of pasture and animal production from Kara cocksfoot and Grasslands Nui ryegrass (Loliumperenne L.) pastures both sown with Grasslands Tahora white clover in two replicates of individually fenced 0.25 ha plots are compared here. Measurements under goat grazing began in September 1989 and continued for the spring, summer and autumn of the following two years. A put and take grazing system (Stevens etal. 1992) was used to ensure a residual grazing height of $100 \mathrm{~mm}$ was achieved while confining 10 measurement goats to each plot during spring and summer. The amount of live weight gain and stocking rate were measured for each season over two years. Pastures were grazed by goats grazing for 7 days with a 21-day regrowth period. Animal husbandry and pasture measurement procedures are described by Stevens $\boldsymbol{e t}$ al. 1992. The liveweight gain and stocking rates of lamb hoggets were also measured 
for the same plots in spring of 1991. Pasture digestibility and protein levels were assessed in spring, summer and autumn in the first year. Samples of the whole pasture in the grazing horizon above $100 \mathrm{~mm}$ were used.

\section{Experiment three}

The dry matter yield of Kara cocksfoot was compared with Nui ryegrass (endophyte Acremonium lolii $=83 \%$ ) in a mowing evaluation at Ceres Research Farm, Canterbury, on a drought prone soil for 2 years after sowing in autumn 1989. The annual rainfall over the trial period was 785 and $605 \mathrm{~mm}$ in years one and two respectively, receiving $60 \%$ more and year two $60 \%$ less summer rainfall than average.

Observation plots of Kara. Wana, Apanui, Saborto and Porto cocksfoots were scored for rust tolerance and establishment vigour over a period of ten years between 1981 and 1991.

\section{Results and discussion}

\section{Establishment}

Cocksfoot establishedmore slowly than ryegrass (Table 1) especially from autumn sowings. This can be attributed to the slower germination of cocksfoot (Charlton et al. 1986). Within the cocksfoot cultivars Kara and Saborto had significantly higher vigour than Wana or Apanui after autumn sowing in Canterbury (Table 1).

Table 1 Establishment features of cacksfoot cultivars

\begin{tabular}{|c|c|c|c|c|}
\hline & & \multicolumn{3}{|c|}{ Pasture yield ( $\mathrm{kg}$ DW/ha) at Rrst harvest } \\
\hline & & Cocksfoot & Ryegrass & Isd $5 \%$ \\
\hline \multicolumn{2}{|c|}{ Southland (late spring) } & 1300 & 2500 & 350 \\
\hline \multirow[t]{3}{*}{ Canterbury } & (autumn) & 290 & 950 & 310 \\
\hline & \multicolumn{4}{|c|}{ Relative establishment vlgour } \\
\hline & Kara & Wana & Saborto Porto & Isd $5 \%$ \\
\hline $\begin{array}{l}\text { Canterbury } \\
\text { (autumn) }\end{array}$ & 100 & 07 & 95 & 12 \\
\hline
\end{tabular}

Pasture production

Under lax grazing in Southland (Experiment 1) Kara produced similar winter and spring yields to Wana (Table 2) but lower summer and autumn yields, and annual yield was 7\% lower than for Wana. Saborto was similar to Kara in spring and autumn. produced more in summer but less in winter. Apanui produced well in spring and summer but was lower yielding than Kara in winter. The pasture production of Kara under goat grazing in Southland (Experiment 2; Table 3a) was never significantly different than that of Nui. Thii supports the principle of high herbage production under lax grazing (Rumball 1982) and suggests that Kara will perform ' well under cattle grazing.

Canterbury yields (Experiment 3 ) show the distinct advantage of Kara over high endophyte Nui ryegrass in dry conditions (Table $3 b$ ). In the year after establishment yields were not high with Kara yielding only $80 \%$ of Nui pastures. Once Kara was established fully, however, it produced $131 \%$ more summer herbage $(\mathrm{P}<0.05)$ and $74 \%$ more autumn herbage $(P<0.05)$ than Nui in a year when summer rainfall was only $60 \%$ of average. This resulted in a significant annual advantage of $51 \%$.

Table 3 P asture production of $K \mathrm{~m}$ cocksfoot compared with Nui ryegrass under lax grazing in (a) Southland and lax mowing in (b) Canterbury

\begin{tabular}{lccc}
\hline (Mean 2 yrs) & Spring & (a) $\begin{array}{c}\text { Southland } \\
\text { Summer }\end{array}$ & Autumn \\
Kara & 4250 & 3230 & 3320 \\
Nul & 5080 & 3030 & 2880 \\
Isd 5\% & 1300 & 1140 & 2030 \\
\hline
\end{tabular}

(b) Canterbury

Spring Summer Autumn Winter Annual

\begin{tabular}{|c|c|c|c|c|c|c|}
\hline \multirow{2}{*}{\multicolumn{2}{|c|}{$\begin{array}{l}\text { Yr } 1 \text { Kara } \\
\text { Nui } \\
\text { Isd 5\% }\end{array}$}} & $\begin{array}{l}1260 \\
2000\end{array}$ & $\begin{array}{l}1080 \\
1010\end{array}$ & $\begin{array}{l}1510 \\
1110\end{array}$ & $\begin{array}{l}290 \\
950\end{array}$ & $\begin{array}{l}4140 \\
5070\end{array}$ \\
\hline & & 500 & 415 & 310 & 310 & 860 \\
\hline \multirow[t]{2}{*}{ Yr2 } & $\begin{array}{l}\text { Kara } \\
\text { Nui }\end{array}$ & $\begin{array}{l}2280 \\
1930\end{array}$ & $\begin{array}{l}2480 \\
1070\end{array}$ & $\begin{array}{l}2370 \\
1360\end{array}$ & $\begin{array}{l}510 \\
570\end{array}$ & $\begin{array}{l}7640 \\
4930\end{array}$ \\
\hline & Isd & 350 & 350 & 420 & 520 & 990 \\
\hline
\end{tabular}

Table 2 Seasonal and annual pasture production (kg DM/ha) and white clover content (wc\%) of cocksfoot cultivars in Southland (Experiment one, 1981-1983) under infrequent grazing

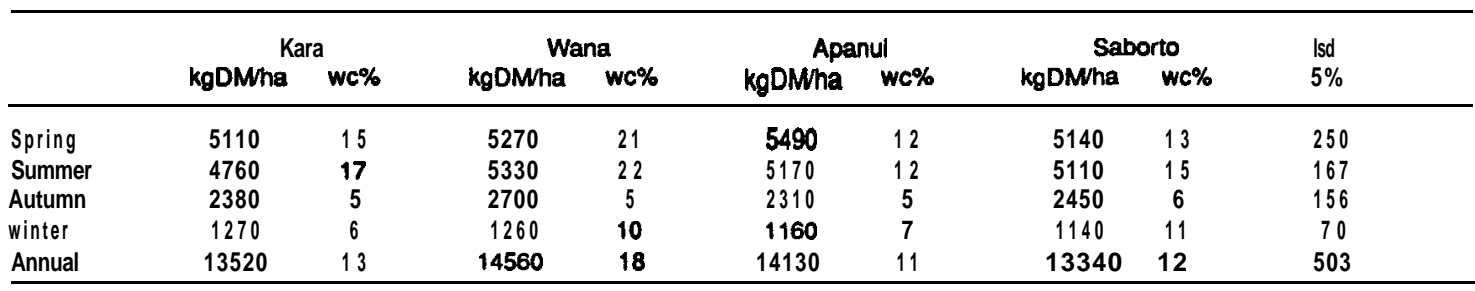


Table 4 Animal production from Kara cocksfoot and Nui ryegrass swands in Southland under hand and lax grazing including individual liveweight gain (LWG), stocking rate (SR) and total production per hectare (ha)

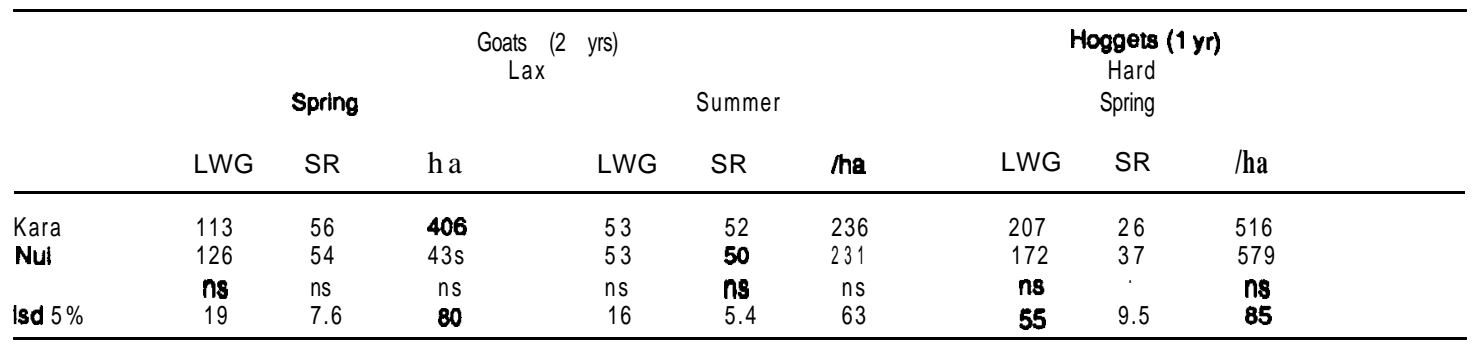

The advantage of cocksfoot over ryegrass in summer and autumn has also been noted in North Island dairy pastures (Judd et $\boldsymbol{a l}$. 1990). This extra production is an important feature for its use to provide improved nutrition for animal growth in dry environments.

These data show the importance of environment in determining the appropriate species choice. Kara is a valuable replacement for ryegrass in the dry Canterbury environment, but produces similarly to ryegrass in the cool moist Southland environment.

\section{Animal production}

Lax grazing with goats produced no differences in either the carrying capacity, liveweight gain or total liveweight gain per hectare between Kara and Nui in either spring or summer when averaged over 2 years (Table 4).

The growth rate of hoggets grazing Kara pastures during spring was not significantly higher than those on Nuipasture (Table 4). The stocking rate was lower on the Kara pastures due to lower pasture production (3390 vs $4280 \mathrm{~kg} \mathrm{DM} / \mathrm{ha}$ for Kara and Nuirespectively) under the closer sheep grazing regime imposed (to a residual herbage mass of approximately $600 \mathrm{~kg}$ DM/ha).

The animal performance gained from Kara pastures in the Gore trial is in contrast to early research which showed that animal growth on cocksfoot was lower than that of animals grazing ryegrass (Davies \& Morgan 1979. Evans et al. 1979). This was attributed to the lower digestibility of older cocksfoot cultivars (Davies \& Morgan 1979; Minson et al. 1964) and their low summer palatability due to rust (Rumball 1984).

\section{Pasture quality}

The digestibility of Kara cocksfoot pastures (Table 5), though lower than ryegrass in spring, was high throughout the Gore trial (Experiment 2) The protein levels of Kara cocksfoot pastures in spring were significantly greater than Nuiryegrass pastures. White clover content of the pasture was 29 and $20 \%$ in the Kara and Nui pastures respectively and may account for the change in the protein levels. The summer and autumn protein levels were similar inbothpashues (Table 5). Cocksfoot is an aggressive grass and can reduce clover content. This is illustrated by the lower clover contents in Kara than Nui pastures in year 2 of experiment 2 (Table 5). There were no significant differences between Kara and Nui pastures in any of the major elements (Casey 1992). Kara cocksfoot (Table 6) had high tolerance of summer and autumn rust infection, being greater than Apanui and Saborto though similar to Wana and Porto. This improves pasture palatability and consequently utilisation during late summer and autumn.

The proportion of leaf in the spring was significantly higher in Kara pastures than Nui pastures (Table 6). The proportion of leaf in Kara pastures increased slightly through summer to peak in autumn, though was not significantly different from Nui pastures in either of these seasons (Table 6).

\section{Other attributes of Kara cocksfoot}

Pest tolerance of pasture cultivars is an important feature in todays low cost farming. Kara cocksfoot has been

Table $\mathbf{5}$ Digestibility and protein percentages of Km cocksfoot and Nui ryegrass pastures in spring, summer and autumn (above residual grazing height) and white clover content in two years.

\begin{tabular}{|c|c|c|c|c|c|c|c|c|c|}
\hline & \multicolumn{2}{|c|}{ Spring } & \multicolumn{3}{|c|}{ Summer } & \multicolumn{2}{|c|}{ Autumn } & \multicolumn{2}{|c|}{$\begin{array}{l}\text { White Clover } \\
\text { Content \% }\end{array}$} \\
\hline & Dig \% & Protein \% & Dig \% & Protein & $\%$ & Dig \% & Protein & Year 1 & Year 2 \\
\hline Kara & 71.9 & 27.2 & 72.1 & 23.2 & & 69.3 & 23.4 & 19 & 4 \\
\hline Nuj & 76.9 & 22.3 & 73.0 & 23.0 & & 77.2 & 22.0 & 19 & 11 \\
\hline & & ' & ns & $\mathrm{ns}$ & & ns & ns & ns & $\cdot$ \\
\hline Isd & 3.5 & 4.13 & 3.9 & 4.3 & & 6.5 & 4.9 & 5 & 6 \\
\hline
\end{tabular}


Table 6 Comparative quality features of Kara cocksfoot compared with other cockefoot cultivas and ryegrass

\begin{tabular}{|c|c|c|c|c|c|c|}
\hline & \multirow[b]{2}{*}{$\begin{array}{c}\text { Relattve rust } \\
\text { tolerance }\end{array}$} & \multicolumn{2}{|c|}{ Winter frosting damage } & \multicolumn{3}{|c|}{ Proportion of leaf } \\
\hline & & $\begin{array}{l}\text { Winter growth } \\
\text { (kgDM/ha) }\end{array}$ & $\begin{array}{c}\text { Spring recovery } \\
\text { (kgDWha) }\end{array}$ & Spring & Summer & Autumn \\
\hline Kara & 7.2 & 250 & 1460 & 62 & 68 & 74 \\
\hline Wane & 7.7 & 140 & 440 & & & \\
\hline Apanul & 6.3 & 400 & 1830 & & & \\
\hline Saborto & 8.1 & & & & & \\
\hline Porto & 7.7 & & & & & \\
\hline Nui & & & & 36 & 67 & $\mathrm{n}$ \\
\hline $\operatorname{tgd} 5 \%$ & & 100 & 340 & 8 & 8 & 7 \\
\hline
\end{tabular}

shown to harbour only low numbers of grass grub when compared with ryegrass pastures (McCallum et al.1990) and in those conditions the production from Kara cocksfoot pastures was significantly greater than ryegrass in the summer and autumn.

Winter diseases particularly winter brown stripe (Scallecotrichum gramineus) play a role in the dieback of cocksfoot. Scoring for this disease in Argentina has shown that Kara had moderate resistance while Wana was susceptible (R. Neldo pars comm). ${ }^{1}$

Frosting damagecanbe aproblem with winter active cocksfoots but this problem is less in Kara than Wana. The winter growth and early spring recovery of cocksfoot plots in Southland were affected by winter frosting. This effect of winter frosting on winter yield and spring recovery was measured on laxly cut plots during the winter of 1978 in Gore when frosts were -4 to $-7^{\circ} \mathrm{C}$ over a period of 6 days in mid June. The winter yields of Kara. though low, were twice that of Wana (Table 6). Apanui was not active in winter and therefore did not suffer winter production losses after frosting. The recovery of Kara in early spring was also greater than Wana, indicating its better tolerance of frosting. The measurement of the effect of frosting on winter feed reserves in the Mackenzie Basin by Scott \& Maunsell (1986) showed that Kara retained a greater bulk of green material in winter than either Wana or Apanui.

\section{ACKNOWLEDGEMENTS}

The authors wish to thank present and past Gore Research Centre technical and farm staff, and Pyne Gould Guinness Ltd staff for their assistance with the research.

\section{REFERENCES}

Casey M.J. 1992. Grazing evaluation of nine pasture mixtures with angora-type goats. Thesis $\mathrm{MAgrSci}$ Lincoln University.

'R. Neldo, Cardielo, Agrotechnica Trebol Sur.
Charlton J.F.L.; Hampton J.G.; Scott D.J. 1986. Temperature effects on germination of New Zealand herbage grasses. Proceedings of the New Zealand Grassland Association 47: 165-172.

Davies D.A.; Morgan T.E.H. 1979. Grazing evaluation of four grass species under upland conditions. Grass andforage science 34: 67-68.

Evans W.B.; Munro J.M.M.; Scurlock. R.V. 1979. Comparative pasture and animal production from cocksfoot and perennial ryegrass varieties under grazing. Grass andforage science 34: 64-65.

JuddT.G.; Thomson N.A.; McCallum D.A. 1990. Pasture management and pasture species for improved dry matter production in south Taranaki. Proceedings of the New Zealand Grassland Association 51: 109- 112.

Levy E.B. 195 1. The grasslands of New Zealand. Wellington Government Printer.

McCallum D.A.; Thomson N.A.; Roberts A.H.C. 1990. Grass grub tolerant pastures and fertiliser nitrogen as an alternative to white clover in pasture subject to grass grub attack. Proceedings of the New Zealand Grassland Association 51: 105 108.

Minson D.J.; Harris C.E.; Raymond W.F.; Milford R. 1964. The digestibility and voluntary intake of $\mathrm{S} 22$ and $\mathrm{H} 1$ ryegrass. $\mathbf{S} 170$ tall fescue, S48 timothy, S215 Meadow fescue and Germinal cocksfoot Journal of the British Grassland Society 17: 298-305.

Rumball W. 1982. Grasslands Kara' cocksfoot (Dactylis glomerata L.). New Zealand journal of experimental agriculture 10: 49-50.

Scott D.; Maunsell L.A. 1986. Winter feed quality of some grasses in the high country. New Zealand journal of experimental agriculture 14: 19-24.

Stevens D.R.; Casey M.J.; Lucas R.J.; Baxter G.S.; Miller K.B. 1992. Angora goat production from different legumes mixed with ryegrass. Proceedings of the New Zealand Society of Animal Production 52 (in press). 